\title{
Efficiency and academic freedom
}

Always inclined to describe grim situations in dispassionate tones, the Vice-Chancellor delivered on Founder's Day 1985 a speech packed with foreboding, as he analysed a four- or five-year plan hatched by the Government and the University Grants Committee. From October 1986 the UGC would begin to shift resources from universities deemed weak to universities deemed strong in research. Some might either go bankrupt or, being deprived of research funding altogether, fall to the rank of Liberal Arts Colleges, as in the United States. Universities (as he might well have reminded his audience) had complained in the 1970s of being treated by the Government as superior grammar schools whose sole function was teaching the young; unwelcome attention was now to be paid to the quality of their research, and the results of inquiries and surveys would be used to establish both the status of an institution and its entitlement to finance. Within a few days, or so rumour had it, the UGC would pass the black spot to some ill-favoured universities. 'It seems to be a central dogma for this Government that all large organisations need to be shaken up, and from such shake-ups advantages flow. The shake-up of the university system is at hand. If it develops in the way that seems to be foreshadowed it will produce much turbulence and not a little acrimony and pain. It might lead to greater efficiency by some measures, but will the quality of the output be improved at the end? I find it hard to convince myself that it is likely ...'

Events would suggest that the Government, like some eighteenthcentury barber surgeon, believed in the therapeutic value of letting blood. Year by year it reduced university funding by a series of 2 per cent cuts, not merely to relieve the taxpayers of their burdens, but to compel the universities to become more efficient. Towards the end of the 1980s the Government ceased to argue that the system had to shrink because the number of youthful customers was declining. It began to sing a new song, which called for an expansion of student 
numbers, a widening of access to universities, and a reduction in the unit of resource, which the UGC had once tried to protect. Allegedly, there was waste and mismanagement in universities. If they administered their resources with greater skill, adopted a corporate ethos and a system of line management, and used more economical methods of teaching (for example, by holding forth to large lecture audiences and classes), they would increase their productivity, churn out more graduates and publications, and be able to do everything that Government and society required of them. Intense competition both for fee-paying students and for research funds would best serve the customers of universities and get them the best deals at the lowest prices. All should live in what Dorothy Parker, discussing a different kind of poverty, called 'a state of stimulating insecurity'.

In material terms, the entire university system would be deprived of some funding, but some universities would fall faster than others. For Manchester and other reputable universities, the main consolations would lie in the occasional year in which (as in 1988-89) the University's block grant appeared for a time to have slightly outstripped inflation, and in the knowledge that some institutions were faring worse than they did, on La Rochefoucauld's principle that 'In the misfortunes of our friends, we always find something which is not displeasing to us.' Relatively modest cuts were sometimes termed 'votes of confidence'. In most league tables, particularly those relevant to the distribution of grant money, Manchester appeared among the top ten or twelve of the forty-odd universities in the country. Only in 1990 did its reluctance to pull in great numbers of additional students cause it to drop down the published lists and remind it forcefully of the fragility of all reputations.

Manchester University's liberal tradition, brilliantly expounded in the past by such writers as Gerald Aylmer, the History lecturer, and Eugène Vinaver, the famous Professor of French, was still in being. It rejected analogies between a university, an institution devoted to free inquiry, and a business corporation dedicated to the pursuit of material profit. Administrative hierarchies, and systems of rewards and promotions which made younger academics dependent on the favours of superiors, were in reality profoundly inefficient. They had always been sanctioned by the customs of Victorian civic universities, but they ought to be modified and not accentuated, because they interfered with the central purpose of the institution. They also weakened its resistance in the face of threats, on account of the mutual suspicion that existed between senior administrators and the rest of the University, 
who were being transformed from colleagues into employees. The growing obsession with competition, the intrusion of the market into academic life, threatened to destroy collaboration and the sharing of secrets between universities.

A major problem, however, was that the Government's tolerance for free inquiry was limited and that what it wanted was immediately useful inquiry, precise accounts of how its money was being employed, and assurances that resources were being well managed. Academics, none the less, found a spokesman for the liberal tradition in the Chancellor who was elected in 1986. Some of them set out to curb the growth of executive power by awakening from its 'ancient, dreamless, uninvaded sleep' the largest and hitherto most passive body in the University's constitutional machinery - the Court - and persuading it, like Tennyson's Kraken, to rise to the surface and roar.

In 1984 the Vice-Chancellor joined a committee established by the Committee of Vice-Chancellors and Principals (CVCP) to conduct a series of 'efficiency studies' of universities and make recommendations. This body consisted of six academics (five heads of universities and colleges and one registrar); of four businessmen, who were chairmen and directors of large international companies, including Plessey plc and the Ford Motor Company; of a civil servant, the Prime Minister's Adviser on Efficiency, with the Head of the Efficiency Unit as alternate; and of Sir Peter Swinnerton-Dyer, the Chairman of the UGC. Two of the businessmen involved were also the constitutional monarchs of universities. Sir Alex Jarratt, the ex-civil servant who presided, was the Chairman of Reed International and the Chancellor of Birmingham University; Sir Adrian Cadbury, the Chairman of Cadbury Schweppes, was Chancellor of Aston University, one of the three which had suffered most gravely in 1981. Jarratt's name was more ephemeral than that of Robbins, and his report far slimmer, but he and his committee likewise promised to leave an indelible mark on British universities; ministers turned to his pages before specifying the reforms they expected universities to introduce in exchange for their grants. Mark Richmond was said to have modified the more forthright opinions of the industrialists and civil servants round the table, but his connection with the report was to cause some difficulty with colleagues.

Jarratt criticised both the Government, for springing on the universities so many exercises in crisis management, and the universities themselves, for their habit of avoiding unpleasantness by imposing a mixture of equal and random misery when faced with cuts. At the core of the document was a call for long-term strategic planning and 
for the identification of strengths and weaknesses by the systematic use of so-called 'performance indicators'. On these should informed judgements depend, and on these should the management rely when deciding (presumably with outside help, for example from the UGC) which departments it should cherish and which it should permit to wither away or even dissolve. At present there were 'pressures to preserve cohesion and morale which lead to a reluctance to set priorities and even to discuss openly academic strengths and weaknesses'. Universities should abandon the comforting fiction that one academic department was as good as another. Appendix G propounded long lists of telltale signs: 'internal' indicators, such as graduation rates, the classes of degrees awarded, teaching quality, and the capacity to attract research grants; 'external' indicators, such as publications, patents, inventions, consultancies, conference papers, medals and prizes; 'operating' indicators, such as staff-student ratios, class sizes, the range of optional courses offered to students, and the supply of books and computers. 'Input' and 'output' should now be measured as though the university were some vast processing plant. Inviting universities to discharge superfluous committees, which consumed valuable academic time, Jarratt and his colleagues implicitly called for more hours to be spent on compiling quantitative records and assessing colleagues' ability. Let talking shops fall silent and filing cabinets bulge with judgmental paper.

The Jarratt report called for the establishment in all universities of a central committee to control resources. It sought to reinforce executive power and the capacity to take hard-headed decisions by emphasising the Vice-Chancellor's role as Chief Executive and strengthening the hand of Council, responsible for financial management, against that of the supreme academic body, the Senate. For 'financial and academic priorities' were 'potentially in conflict' and some friction might increase the health of the body politic. No longer should the ViceChancellor be the scholar who did the will of Senate, which was a naturally conservative body (this description, which perhaps applied to the Manchester Senate, would scarcely have fitted Stopford, Mansfield Cooper or Armitage). Seats on Council, urged Jarratt, should go to young and vigorous business executives, at the expense, if need be, of the representatives of local authorities. Deans and heads of departments should acquire managerial skills and not be mere scholars reluctantly doing a little administration on the side. Deans should be expected to pursue the policies of their universities rather than the sectional interests of their constituents, and heads of departments 
should henceforth be appointed by councils on the recommendation of Vice-Chancellors after due consultation. Academics' performances should be 'appraised' every year 'with a view to their personal development' and the advancement of their careers.

Furthermore, the Jarratt Committee disapproved of the concept of 'academic-related' staff, of librarians, administrators, accountants, engineers, assistant bursars or managers who enjoyed tenure and were paid on the same scales as academics. Let their conditions of service be determined instead 'by the nature of their duties and in relation to similar employment outside the university'. It was better that university administrations should be unified under a single head, a registrar or secretary - not divided, as in Manchester, into two or even three domains of equal standing, under a Registrar, a Director of Finance and a Director of Estates and Services, lest the Vice-Chancellor have to spend his valuable time co-ordinating their efforts.

In general, stated the Jarratt Committee, 'in our view universities are first and foremost corporate enterprises to which subsidiary units and individual academics are responsible and accountable'. The notion of a university, or its board of directors, being accountable to its members seemed to have disappeared entirely. All these measures were represented as crucial to the survival of the organisations under review.

The University received the Jarratt report with due caution. Some of its recommendations reflected existing Manchester practice; the University Council eventually told the UGC that Manchester's JCUD was 'almost exactly in line with the central planning and resources committee described by Jarratt', and that planning and resources subcommittees already existed for the five principal academic areas. Other recommendations, concerning appraisal schemes and the appointment of heads of department, were under discussion. The Council were saddened by the resigned tone of parts of the report, which seemed willing to accept that no-one would pay for the huge backlog of maintenance and repair work on university estates. Donald Redford, the Chairman of Council, did not seem enamoured of the 'creative tension' which Jarratt advocated. 'All laymen', he said, 'are doubly sensitive about creating academic problems. We have no wish to depart from the strong tradition of not bringing Council and Senate into confrontation.'

Swinnerton-Dyer had written that it had not been Jarratt's intention to 'offer an inappropriate industrial solution' to the management problems of universities, but not everyone believed him. Those who referred to the Vice-Chancellor as the Chief Executive usually did so 
with satirical intent. Some found it strange that, given the poor performance of British industry, its managerial techniques should be held up as models. Some came to believe, in the years which followed, that the talk of five-year plans savoured more of a kind of anaemic Stalinism than of any policies appropriate to a liberal institution where inspiration ought to spring from within the individual, could not be imposed from above, and did not gain from being constantly watched and controlled. Would the rise of 'senior management teams', the stress on 'leadership' rather than self-government, create a world to which academics had become incidental?

Lessons, said many, not without malicious satisfaction, should be learned from the failure of one appointment in particular. In 1984 a middle-aged accountant who had served ICI for twenty-three years was appointed to the post of Director of Finance. He was expected, as This Week told its readers, to 'bring wide industrial experience to the task of running the University at a time of financial strain'. For whatever reason, however, the University's problems appeared to overwhelm the man of promise. When he resigned his post after barely a year rumours spread that the University, which had not insisted on a probationary period, had been forced to make a substantial ex gratia payment. Pointed questions were asked in Senate and Court, and a 'torrent of information-free verbosity' from one ProVice-Chancellor did little to allay discontent. In December 1986 two academic members proposed to Court that in future no-one should be granted tenure immediately unless they had previously been employed in a university (Manchester or another) for at least three years. Their motion was referred to Council, which, while talking of 'flexibility' and declining to accept the proposal formally, agreed to take some notice of the misgivings which lay behind it. Wisely, the University now appointed to the Director's post one of its Deputy Bursars, Garth Roberts, who had spent twenty years becoming inured to its ways and had introduced a number of innovations. Industrial experience, it seemed, would not always equip a person for academic, or even para-academic, life.

In the summer of 1986 the election of a new Chancellor gave liberal academics a chance to reaffirm the old values threatened by Government interference and the spread of 'managerialism'. The Duke of Devonshire had resigned and been highly praised as 'a model Chancellor, always accessible but never interfering'. Even his many admirers would not have claimed that he had an intimate knowledge of the working of universities; nor, perhaps, would he have thought it proper 
to acquire one. Five of the University's seven Chancellors (three of whom had been Dukes of Devonshire) had inherited titles long ago established; two of them, Morley of Blackburn (1908-23) and Woolton (1944-64), had been newly created peers. In 1986 the Chairman, Clerk and Committee of Convocation made some attempt to follow tradition by nominating Shirley Vaughan Paget, the Marchioness of Anglesey, although she was also the first woman candidate for the job. Neither a nonentity nor a philistine, she had a respectable record of public service, to the environment, to the arts, and to Women's Institutes; she had earned her own title as a Dame of the British Empire. She was the daughter of two novelists, one of them Hilda Vaughan, and the other the late Charles Morgan, the author of The Fountain, The Voyage, Sparkenbroke, The Judge's Story and other works alternately admired and derided by the intelligentsia from the 1930s to the 1950s. But, although she had received an honorary Doctorate of Laws from the University of Wales, she appeared to have no other experience of universities, and it could well be argued that in the 1980s the role of a Chancellor needed to be more than emblematic and ceremonial. The Marchioness lived in Llanfairpwll, Gwynedd, and had no obvious connection with the Manchester region.

Although there had never previously been a contested election, and many people would therefore have supposed that it was for the officers of Convocation to find a willing candidate and for the rest of Convocation to back their choice, members of the University became restive and uneasy. A postgraduate student, John Spencer, put up against the Marchioness like a stalking-horse testing the support for an established Conservative leader, in the belief that in the interests of academic democracy there ought to be a contest. His move turned out to be more than just an expensive stunt.

The election of the Chancellor lay in the hands of the Convocation, which had 80,000 members. Under Statute XVI, of 1973, the Convocation had come to include, not only the whole body of Manchester graduates, but also all members of the Assembly, many of whom did not hold Manchester degrees. Broadly speaking, the Assembly comprised all persons who held academic appointments and were actively involved with the University. They could be expected to influence strongly the result of any election, especially because the tight timetable imposed by the ordinance on the subject tended to disenfranchise overseas voters. Perhaps a contested election had seemed unlikely; let one unexpectedly occur, and the defects of the arrangements became apparent. The Chairman and Clerk of Convocation 
were now involved both in conducting a ballot and in sponsoring a candidate, a confusion of roles which put their impartiality in doubt. They had allowed little time for anyone to put up a rival contender for the title. Certainly no-one would be able to secure a list of backers comparable with the battalions of supporters who had lined up behind the Marchioness, as a result of the officers' pre-emptive strike. Despite this handicap, a group (sometimes described as 'rebel lecturers') succeeded in organising support for a serious challenger, at which point the postgraduate student withdrew from the contest.

The new candidate was John Griffith, Emeritus Professor of Public Law at the London School of Economics. He had written (among much else) a famous book on The Politics of the Judiciary; he had been a friend and collaborator of one of Manchester's greatest lawyers, Harry Street, who had died suddenly when walking in the Lake District in 1984; and he had delivered in Manchester the first Harry Street Memorial Lecture. As a founder member of the Council for Academic Freedom and Democracy (CAFD), Professor Griffith had led in 1970 the unofficial investigation into the decision of a Manchester committee not to appoint a young lecturer critical of the establishment, Anthony Arblaster, to a permanent post in Philosophy. A CAFD pamphlet had invited the University to clear its name by authorising its own judicial inquiry into events that cast a shadow upon its integrity. Rhys Vaughan, the solicitor defending student members of the CND charged with offences at Burtonwood in 1984, had used arguments which John Griffith was said by Mancunion to support - to the effect that it was lawful to use reasonable force to prevent the greater crime of preparing to inflict indiscriminate murder and destruction upon fellow creatures. Some supporters of Griffith saw in him the champion of the oppressed who would be capable of overcoming the University's reluctance to protest openly at the ill-treatment of Sarah Hollis and Steven Shaw. This issue apart, he was an outspoken critic of all measures that threatened the independence of universities in the face of government, and the freedom of individuals within them by the strengthening of hierarchies.

When agreeing to stand, John Griffith doubted his chances of winning the contest, but thought it important to challenge 'establishment procedures'. Unlike the Marchioness of Anglesey, he issued a statement to members of the Assembly (to send it to all members of Convocation would have been prohibitively expensive). ' . . . it is clear', he wrote, 'that the next five years or so will be the most critical since 1946. Progressively, universities are being drawn more and more 
under the control of central government authorities. This is a tendency I have continuously opposed . . . My principal concern today is with the crucial necessity that universities, their students and their academic staffs, should remain free to pursue their primary purpose of enlarging the understanding of their disciplines ... When the universities are required to divert their efforts to the short-term ends of politicians, they begin to lose their freedom and to die.'

Ballot papers went out in preparation for an election to be held on 4 July 1986 . They listed the number of persons who had nominated each candidate, thereby creating the impression that the Marchioness of Anglesey (1,100 names were arranged in twenty-four full columns) enjoyed overwhelming support. Between seventy and eighty supporters had nominated John Griffith and succeeded in occupying a mere three half-columns. For all this, Griffith, believed to have been strongly supported by the Assembly, won the election by an ample margin, mustering 2,881 votes against his opponent's 2,018; about 6 per cent of the electorate had taken part in the election. Lady Anglesey was gracious in defeat, saying that at least the electors had wanted somebody Welsh, and that supporters of Professor Griffith had run a very professional campaign. Some of the new Chancellor's supporters declared in their triumph that the result humiliated, not the losing candidate, but 'the cabal of academics and businessmen who feel free to run the University as if it were their family estate'.

By custom the formal duties assigned to the Chancellor consisted of presiding at meetings of the Court and of conferring honorary degrees. Little else was laid down. The Chancellor was expected to use on the University's behalf such influence as he possessed in high places, and his rights might perhaps have been explained by invoking Walter Bagehot on the Victorian monarchy - they surely included 'the right to be consulted, the right to encourage, the right to warn'. Professor Griffith would clearly be no King Log; might he, perhaps, prove to be King Stork and gobble up some of the University's juicier frogs? The students greeted him with good reason as a sympathetic presence, a 'voice on our side': he became the first Chancellor to address an Introductory General Meeting of the Students' Union and made diplomatic but firm statements in an article, 'Breaking the Mould', which appeared in Mancunion for 9 October 1986. 'My role is a limited one. The ViceChancellor is the person responsible for running the University and I have no doubt that there are many areas in which I shall have no right to interfere or, indeed, would think of doing so. I want to be helpful to the University as a whole. However, I am very conscious, from my 
experience, that there is not just one unified view, but many views in a university. I certainly shan't be able to please everybody.'

Griffith's suggestion that the students needed some kind of ombudsman, separated from the University hierarchy, created alarm. It was inevitable that members of the central establishment should see him as the leader of a faction, as one who encouraged the dissidents with whom they had little patience ('the students, the unorthodox left-wing members of the Association of University Teachers, and the non-professorial members of Senate'). Perhaps, however, his role was really to restore balance and to act as a mediator, ensuring that proper attention was paid to the opinions of groups which higher authority was inclined to treat dismissively or to patronise with a show of courtesy.

Most controversial was the Chancellor's decision to break with precedent by attending meetings of the University Council, of which he was a member by virtue of the University statutes. Lay members, or some of the more senior among them, were as shocked as if the monarch herself had materialised in the midst of Margaret Thatcher's cabinet or joined an Old Bailey judge on the bench. University liberals, however, thought Council needed watching lest, in the name of the Jarratt report and despite its Chairman's assurances, it begin to encroach on the academic territory of Senate. The Chancellor's analysis of Council meetings was less than complimentary: one or two of the laymen might be well informed about the issues discussed, but the rest would simply back the Vice-Chancellor. Since he and the Chairman had usually thrashed out all contentious matters before the meeting began, there was little chance of getting decisions reversed and the Chairman was unlikely to oppose the Vice-Chancellor openly. When an officer of the Students' Union complained of being patronised at Council in 1987, the Chancellor sympathised and said so; he asked only that her successor should inform him in advance of matters which the students intended to raise ('it is difficult to intervene off the cuff and without background information'). As he later said, he was 'on tap, not on top'.

While attending Council the Chancellor called for greater openness on the part of Council's specialised committees. Surely the Estates and Services Committee ought to consult about proposals affecting the environment, and the Finance Committee ought to provide more information to justify heavy investment in a company which was losing money, the University's own Vuman. His views diverged from those of the Vice-Chancellor at a Council meeting in February 1989 which discussed the possibility of docking academics' pay if, by way 
of protesting against an inadequate salary settlement, they refused to examine their students.

It was plain that the Chancellor had no time for the theory that the University ought to resemble a company or adopt a corporate identity. In his view, a university was essentially a framework within which individuals performed the functions of teaching and research as effectively as they could. His remarks on this subject, for example at Founder's Day lunches, were greeted with visible embarrassment at parts of the high table, but brought tears of relief to the eyes of some of the academics present, who had begun to fear that the liberal traditions of the University would be buried in an unmarked grave.

Many of the Chancellor's critics conceded that he presided expertly and with impeccable dignity and fairness over the Court; a genuinely independent Chairman, he had no need to seek rulings from the ViceChancellor or the Registrar. In theory at least the Court had always been the sovereign body within the University and the long stop of the constitution, since all statutes and ordinances depended on Court's endorsement. Some universities were accustomed to send statutes directly from their own councils to the Privy Council for final approval, but this was not the practice in Manchester. The Court did not figure in Jarratt's calculations, but technically Court, and not Council, reigned supreme in the University. However, since it normally met only twice a year, it could hardly become involved in the day-to-day business of running the institution, and there was some temptation to treat it as a cipher and take its approval for granted.

Before the mid-1980s, the Court had for many years done little more than acclaim decisions already made by Council and Senate, approve the University's annual report and accounts after little or no discussion, and listen politely to statements made by the Chairman of Council, the Treasurer and the Vice-Chancellor. George Wilmers, the mathematician, described it in 1988 as 'a rather motley collection of some 200 souls', composed in such a way as to 'give an impression of democratic accountability while ensuring absolute control by a small camarilla which dominates Council', and thus provide legitimacy to a 'self-perpetuating oligarchy'. Now, however, it became a forum in which contentious matters already discussed by Senate and Council, such as the ordinance on student discipline, were reopened before a different audience. Here, University dissidents could sometimes join forces with City councillors serving on Court and oppose members of the University Council. It was doubtful whether Court could enact legislation which had never been before Senate or Council, but it was 
possible to initiate at Court discussion of certain matters, such as equal opportunities policy, which were then referred to Senate and Council for further action. Buried grievances were disinterred at Court in the presence of journalists, to the potential embarrassment of higher authority. Wilmers and his colleagues urged members of the University to use their right to vote for representatives of Convocation on Court (there were thirty of these and they accounted for about 15 per cent of Court's membership). It was surely desirable, or so they argued, to keep these places out of the hands of nominees of the central establishment.

Court first tested its new Chairman in December 1986. Addressing the Court the previous January the Treasurer had warned that the pay claims of university teachers, rushing like lemmings over the precipice, would lead to redundancies by forcing the University to shed staff it could no longer afford. When similar remarks appeared in the financial report and were coupled with predictions that a change of government would make no difference, they caused considerable offence. Ambiguous standing orders failed to make it clear whether an unsatisfactory Treasurer's report had to be rejected in toto or whether it could be amended. The Chancellor persuaded Court to vote on the matter and it chose to refer the report back to Council by a majority of 50 votes to 26 .

The Chancellor's opinion carried great weight when an important constitutional issue arose as an indirect consequence of the Jarratt report. Following Jarratt, the University had determined that heads of departments should henceforth be appointed by Council on the recommendation of the Vice-Chancellor - the effect being to cast them in the role of middle management, responsible, not to their colleagues, but to the University's board of directors. In the session of 1989-90 Senate and Council followed up this move by proposing that heads of departments should now form an order or category of persons fit to be represented on Court. Indeed, they should have thirty places on it, as many as Convocation, for Senate recognised that 'Court had a key role to play at the apex of the University's governing structure'. Since the nine deans of the faculties were also to sit on Court, the 'managerial' component of the academic element on Court would - according to George Wilmers's calculations - increase from 54 to 75 per cent. This reform, in the view of critics, smelt perhaps of gerrymandering and certainly of a growing desire to manage Court lest it block vital legislation. But the Chancellor discouraged the move by pronouncing that the reform could properly be effected only 
through a change of statute and not a mere ordinance, as had been proposed. For it would bring about a major constitutional change by reducing the proportion of lay persons on Court. No statute could pass without securing a two-thirds majority in Court, and there was little prospect of obtaining this (a change of ordinance would need only a bare majority, of 51 per cent). Although the deans got their days in Court the heads of department did not, and the proposal which concerned them was shelved if not dropped.

Chancellor and Vice-Chancellor made an odd couple, and it was hard to resist the impression that each was there to mind the other. Relations between them were correct though not cordial, and they occasionally joined forces - for example, to write to the quality papers about the police inquiry into the Brittan affair. They were seen, if not as determined opponents, at least as representatives of contrasting points of view. Indeed, the Chancellor, addressing the Students' Union in 1988, advised: 'Don't get us mixed up. He wouldn't like it, and I certainly wouldn't like it!' Interviewed years later, Richmond remembered Griffith's remark about him: 'I don't think I've ever met anyone I like quite so much, with whom I've disagreed so profoundly!' For his part Richmond saw conflict in the contrasting roles of the Chancellor as the impartial Chairman of Court, which was the presiding body, and as an active member of Council, which was one of the recommending bodies. '. . . if you actually quoted the legalities to him, being a lawyer he always backed off . . . he was almost like a monkey, wanting to get round the hurdles, but if you actually stated the hurdle, he'd always come back behind it . . .' Richmond recalled his distrust of the Chancellor's willingness to issue aggressive or negative statements about the police - he referred, perhaps, to a sharp exchange in print with Sir Cecil Clothier, the Chairman of the Police Complaints Authority, after the publication of Griffith's article, 'A watch-dog with no bite', in The Guardian in 1987.

However, both Richmond and Griffith, in their contrasting styles, were outspoken critics of the Government and spirited defenders of academic freedom. In a pamphlet, The Attack on Higher Education, published by CAFD in 1987, and in an article in the THES, the Chancellor sought to expose the sinister intentions of the Government and their determination to conscript the universities into meeting the immediate needs of the economy. These proposals appeared in Government White Papers, soon to be translated into legislation through the Education Reform Bill passing through Parliament in the session of 1987-88: 'The whole amounts to a potentially complete take-over of 
policy-making in higher education ... It is an almost total usurpation, a dissolution of the university system comparable to the dissolution of the monasteries.' Attempting to strike a conciliatory note, the new Undersecretary for Higher Education, Robert Jackson, jibbed at Griffith's description of the Government's approach to universities as 'totalitarian' in design. Writing in The Observer, the Chancellor doubted the Government's capacity to 'decide how many Japanese linguists . . . heart surgeons . . . and perhaps even a few historians, archaeologists, philosophers and sociologists we shall need in 1995'. He added that 'The dangerous folly of this government lies in its mistaken assumption that politicians and their appointees know better than the consumers (students) and professionals (industry and academia)'.

It fell to Richmond, as Chairman of the CVCP from 1987 to 1989, to lead much of the University lobbying against the more radical provisions of the Education Bill. The greatest dangers were that the Secretary of State for Education would acquire almost limitless powers to intervene in the affairs of universities; that financial relations between Government and universities would henceforth be ruled by a so-called system of contracts, which would specify in detail what each part of a university was expected to do in order to earn its money; and that the UGC would give way to a new body, the Universities Funding Council (UFC), which would have no power to advise Ministers on its own initiative, but have to wait for them to seek its opinion. As Griffith wrote, the proposed contracts would not be true contracts but rather devices to extend central control, in that universities could not freely choose whether or not to be bound by them. Nor were arrangements to be made for independent adjudication if one of the parties supposedly failed to keep its side of the bargain. The Department of Education and Science would assess a university's performance and renew or withhold funds in accordance with its own judgement. That express references to contracting disappeared from the Bill (it was said to cause problems for parliamentary draftsmen); that the Secretary of State agreed to limit his own powers; and that the Universities Funding Council gained the right to volunteer advice: these things were due at least in part to the efforts of the CVCP. An official eulogy of Richmond, on his departure from the University in 1990, declared that there was no stouter defender of academic freedom.

It was now certain that the Government would seek to abolish the strong form of tenure which prevailed in most universities and seemed to them like a hindrance to efficiency. Commissioners would descend on university statutes and overhaul them in such a way as to 
allow staff appointed to the retiring age to be declared redundant before they reached it. Certain safeguards were introduced in order to prevent universities from solving their financial problems by dismissing costly senior staff and replacing them with juniors engaged to do the same jobs for smaller salaries. It would be permissible to declare redundancies only if a university intended to abandon an activity altogether, in which case it would be entitled to dismiss persons appointed to engage in this pursuit. Could academic freedom survive if dismissal for financial reasons became legitimate? There was a struggle to include in the Bill a clause defining and protecting academic freedom which the commissioners would be bound to respect, and it was eventually stipulated that any revised statute would have to 'ensure that academic staff have freedom within the law to question and test received wisdom, and to put forward new ideas and controversial or unpopular opinions, without placing themselves in jeopardy of losing their jobs or privileges'.

Richmond's pronouncements on the subject were forthright and clear. At the annual residential meeting of the Vice-Chancellors and Principals, in Manchester in October 1987, he said that 'Members of the Committee have themselves experienced the sort of pressure that can be brought to bear on academics by the likes of Joseph McCarthy if they do not feel secure in speaking their minds. This is not a problem now, but times can change.' At a national seminar in London, organised by the scientific journal Nature in January 1988, he argued for three fundamental freedoms - not only to question received wisdom, but also to research on subjects of as yet unrecognised importance, and to be protected from direct and narrow political interference by the Government of the day. For Manchester University there was at least one poignant reminder of the damage that could be inflicted by governments which decided that an academic subject was superfluous or undesirable. Teodor Shanin, the Lithuanian-born Professor of Sociology, arranged in 1989 for young Soviet sociologists to attend summer schools in Manchester and to rectify, on behalf of Gorbachev's regime, the shortage of sociologists in the USSR which had occurred 'in the generation of Brezhnev'. Sociology had then been proscribed as a bourgeois discipline, thus creating an extraordinary generation gap, for leading Soviet sociologists were either in their sixties or in their twenties, with nobody in between.

Despite its desire to see an end of tenure, the Government did not attempt retrospective legislation. Persons granted tenure before 20 November 1987 were entitled to keep it, unless they entered upon a 
new contract of employment - for example, by accepting promotion. Rise from lecturer to senior lecturer, or accept a chair, and the price would be forfeiture of an important contractual right, so that the most able academics might well become the most vulnerable. In summer 1988 the Secretary of State, Kenneth Baker, named the five commissioners; they included two academics, Lord Butterworth, who had been one of the principal targets of E.P. Thompson's Warwick University Ltd., and Professor David Williams, the Principal of Wolfson College, Oxford. Negotiations with the University of Manchester, such as they were, turned on the meaning of a Model Statute which was intended to apply to all universities but could be adjusted to local situations. Stipulations of the Education Act of 1988 were not open to discussion. A draft of the Model Statute reached Manchester early in 1990 and gave rise to much consultation and to-ing and fro-ing. An alarming clause which included as grounds for dismissal 'conduct liable to bring the institution into disrepute' was not in the end included. Incorporated as the revised Statute XVII, the new arrangements passed the Privy Council in November 1992. Members of Council were perturbed by the commissioners' failure expressly to limit the grounds for dismissal to good cause or redundancy. In principle, therefore, dismissals could be sought on other grounds, "for example on the wholly imprecise common law ground of "fidelity", 'thereby casting doubt on the concept of academic freedom as the Statute's guiding principle'.

Compulsory redundancy was still beyond the pale in the late 1980s. But the University could balance its books only by shedding a number of academic staff and by again encouraging early retirements, this time of younger staff, and on less generous terms than before. Turnover in some areas of the University, especially in Arts and Economic and Social Studies, remained very low; in Law, in summer 1987, it suddenly seemed alarmingly high, as a result of deaths, retirements, appointments to senior posts elsewhere, and secondments to the Law Commission. Underfunded Arts folk, their morale wilting, complained that expensive Science was getting all the bonuses while they were deemed to be in deficit. Against this it could be argued that faculties such as Science and Medicine, more favoured by the Government, were compelled to support supine and querulous Arts, which had not made its savings, and whose members were unfit for employment outside the university world. In September 1985 the University was able to fill three out of every five posts that fell vacant, but by May 1986 the proportion had dropped to one out 
of three and the Vice-Chancellor was saying that in principle there should be no replacements in Arts. Possible solutions, as yet mild ones, began to occur to the administration - that academics in the areas which had not made savings should seek secondments and take leave without pay, or that such departments should justify their existence by taking on extra students and increasing the University's income from fees.

Late in 1986 the University expected to have to seek about seventy early retirements by the end of the decade, for which the UGC would provide some but by no means all of the finance. Many regretted the move; Professor Ranger, about to depart for a chair at Oxford, lamented the disappearance of the 'grandfather factor', of older and wiser academics, from the University scene. In August 1987 the ViceChancellor wrote to all members of the academic staff over the age of fifty, encouraging them, if so minded, to apply to take early retirement in the years 1988,1989 or 1990 . When a chair committee resolved to appoint a candidate already in his late forties, a bold spirit asked the Vice-Chancellor which communication he proposed to send him first a letter of appointment or an invitation to take early retirement. 'Shut up!' was the rejoinder. Over a hundred applications arrived, but the management interest in keeping staff was invoked more rigorously than before, and only ninety passed muster (seventy-four academics and sixteen members of the academic-related staff). On this occasion there would be nothing to prevent the University from replacing staff lost by early retirement.

Among Jarratt's recommendations were schemes for appraisal and development which would keep most academics under annual scrutiny throughout their careers and encourage self-betterment rather than torpor. A Senate committee had accepted the need for some such arrangement in order to convince Government and society that academics deserved their pay and relative security of employment, and to ensure that they could be removed from office only by 'due process'. Although it offered many refresher courses to fee-paying students engaged in other occupations, the University appeared to be doing little to help its own members towards professional advancement. Appraisal schemes were on the cards from 1985 onwards; pay settlements began to depend on their introduction; and the University made serious attempts to organise them from 1988.

A working party of five, headed by Professor J.D. Turner of Education, considered the question of appraisal and made recommendations. Hitherto most lecturers had encountered a searchlight at only 
three points in their career and at long intervals - first, when they were considered for tenure; secondly, when they approached the 'barline', a hurdle which had to be surmounted after eight or nine years' service before proceeding to higher points on the salary scale; and thirdly, when, if ever, they sought promotion to the rank of senior lecturer. These occasions apart, they would probably receive little systematic attention, and some would have been resentful if they had. Sixty-five departments answered the working party's questions. It appeared that only half conducted a regular review of their teaching staff, that only twenty-one conducted interviews at which their problems and progress were explored, and that only twenty put out questionnaires seeking student opinion on teaching. Professor Turner's party now urged Senate to call upon all departments to design schemes which would involve annual interviews by trained appraisers and reports of these encounters which would be placed on record and might be used in promotion exercises. Appraisal was generally to flow from the top downwards, but some of the more democratic departments salved their pride by providing for 'reverse appraisal', which would allow the appraisee to give the appraiser some opinion of the appraiser's performance. Professors were to undergo a biennial review by Pro-Vice-Chancellors, some of whom softened the process by visiting them in their rooms. Even the Vice-Chancellor was to be appraised by the lay officers of the University, who, for this purpose, would become the gods of Olympus or Valhalla, subject to scrutiny by no higher power.

In the summer of 1988 the University engaged a consultant, Roger Pryor, who had once been Chief Psychologist to the Australian Government Public Service Board, was now the managing director of Interactive Skills Ltd., and was helping a number of British universities to put appraisal schemes into effect. There was to be a 'pyramid system', in which the newly acquired expertise would flow downwards from the apex, a small elite being trained to train others in the new art, and the Vice-Chancellor and senior administrators attending the first day school. Progress was delayed by the AUT's refusal to cooperate with appraisal schemes until an acrimonious pay dispute was settled, but with this resolved the programme gathered momentum. Numerous senior academics attended day-long sessions at Holly Royde in West Didsbury, at which they engaged in role-playing, analysed each other's body language and assumed the guise of wellknown departmental types, which ranged from the old soldier through the professional cynic to the victim of writer's block. They 
were advised not to be inquisitorial, warned not to set their colleagues unattainable goals, urged to encourage them to do what they did best, and treated to a John Cleese video on how not to perform the task. For many it was the only formal training they had ever received at the University's hands. They then went forth to put their newly acquired skills into practice.

Most appraisees, at least until the novelty wore off, enjoyed the experience of discussing themselves and grumbling about the University ('whoever appraises me is going to get an earful'). Self-criticism was often more in evidence than judgements from on high. One or two pompous characters lectured their appraisers with magnificent hauteur, whilst a few insecure souls regarded any hint of criticism as evidence of a plot to get them sacked. In general, however, the scheme worked smoothly enough and encouraged communication more often than it provoked resentment.

To counter the charge of failing to train its own people systematically, the University set up a Staff Training and Development Unit for the benefit of academics, para-academics and support staff. It was designed to bring together the activities of the Staff Teaching Workshop (used mainly by the Faculties of Medicine and Science) and those of the Training Section of the Establishment Office. A Lecturer in Adult Education was appointed to direct the new organisation and saw his work as 'harnessing human resources to the tasks that have to be faced in the more efficient and cost-conscious world of today'. The implied analogy between University staff and cart horses was doubtless accidental.

In Manchester the term 'head of department' had traditionally been regarded as faintly improper. Departments were ruled collectively by all their professors, and only in the absence of professors was a member of a department officially appointed to be its head. In 1986, however, as though in obedience to Jarratt, the Senate altered the role of professors by detaching their office from automatic managerial responsibility and associating it with 'academic leadership', a term perhaps intended to denote the intellectual influence which many saw themselves exercising. This reform did address the problem of the good scholar who had no capacity for administration but none the less refused to delegate authority. Another aim was to identify more precisely where responsibility lay, particularly for the control of resources, which increased in importance as resources shrank.

Departmental arrangements had varied. Sometimes the professors had recognised one of their number as so pre-eminent, or so enamoured 
of administration, that he or she could be regarded as the permanent head of department; other professors had rotated the job of speaking for the department, appointing a temporary chieftain to serve for perhaps three years; others still had managed to act as a headless body, dividing their duties 'along functional lines between two or more of them', and evading the question of which one, if any, was supposed to be the queen bee. If control over resources was to be devolved from the centre to a lower level - as it might be - it would become more important to identify a controller, and to be sure that this was one person and not a committee.

The reform could naturally be interpreted as part of a threatening managerial strategy, an attempt to put Vice-Chancellor's narks in charge of every vital point in the University. In practice, however, the appointment of heads of department depended on consultations conducted by the dean of the faculty concerned and not on the personal favour of the Vice-Chancellor. Multi-professorial departments generally wanted one of the professors to take charge of them, for they still clung to the notion that professors were paid to assume administrative responsibility. Should a department refuse to back a professor's candidature, as occasionally happened, he or she might be deeply offended and apply for a job elsewhere. In justice to Jarratt, it should be said that his committee had insisted that heads of departments should be obliged to consult and inform their colleagues; the University's charter and statutes had never done more than that.

By 1990 a system of devolved budgets was on the way, established in the interests of greater accountability for public money. Revenues were not supposed to disappear without trace into the maw of the University, and it must now be made clear how and where they were spent. Hence every department was to be assigned to one of thirtyseven 'academic cost centres', which corresponded to categories used by the UGC and its successor, the UFC. Cost centres were foci for the spending of money, and they ranged from a cluster of clinical medical departments at Centre 01 to the entire Faculty of Education at Centre 37. Some large and distinctive departments, such as Chemistry, Pharmacy or Computer Science, formed centres entire of themselves, while smaller entities, such as social science or language departments, were grouped together into many-celled units. This reform set out to bring more closely together income and expenditure (or, as official language had it, 'the allocation of resource and its actual use'). It would then become possible to show how a share of the block grant, plus fees, plus research overheads, plus equipment grant, plus other 
items, flowed into an academic pool, and how these things flowed out again in the form of salaries and wages and other expenditure. Cost centres would to some extent be able to cross-subsidise each other. Heads of departments would no longer be founts of academic wisdom and petitioners of higher authority, like feudal lords seeking royal favours for their vassals. Instead, they would become resource managers, entitled to manage their budgets as they would 'within agreed constraints'.

Efficiency in universities, their ability to attract, retain and inspire their staff, depended to some extent on the range of incentives and rewards at their disposal. Only idealists would continue to praise universities for teaching people to despise the money they prevented them from earning. In the early 1980s most lecturers had before them only the limited prospect of progressing by means of annual increments to the top of their salary scales. Once a lecturer had passed the bar-line, these increases were automatically granted and were not related to performance; opportunities for promotion to a higher rank and a higher scale had become very limited; and there was every sign that university salaries would keep pace neither with inflation nor with those commanded by other professions.

When settling money on universities each year, the Government would allow only a few per cent for salary and wage increases. Should the university employers, the Vice-Chancellors and Principals, agree with the AUT through their national negotiating machinery to pay anything above this allowance, the Government would almost certainly refuse to compensate them, and the universities' financial difficulties would become even more grave. On the other hand, if the heads of institutions stood their ground and closed their fists, they would fail to attract staff of the right calibre, especially in engineering, technology and academic support services, and they would probably provoke damaging strikes. This Week greeted the appointment of Tony Birley, the Professor of Ancient History, to a chair at Düsseldorf in 1990 as an example of a new brain drain which flowed in the direction, not of the United States, but of Europe, and was the result of poor salaries and working conditions in the United Kingdom. Sir Mark Richmond said in May 1990 that the 'most crucial' and 'most shattering' single event of his time in Manchester was the 24 per cent pay increase awarded in instalments over the years 1986 to 1988, when UGC funding allowed for a rise of only 14 per cent.

In 1988-89 the AUT's demand for a cost-of-living award, backdated to 1 April 1988, brought universities close to a general strike. 
The national AUT voted in favour of refusing to examine students from 9 January 1989 onwards, thereby committing a breach of contract on a massive scale. Although for the time being few or no Manchester examinations had been derailed, crisis loomed in the summer. Students, whose careers were at stake, might sue the University if it denied them their degrees; the Registrar warned that the University had at its disposal legal remedies, including deductions of salary for failure to do the work; Council asked itself in February whether further admonitions would inflame the situation, and postponed sending them out until late March. The Senate recommended passing an 'enabling ordinance' which would empower the Vice-Chancellor, if need be, to appoint special Boards of Assessors (how they were to be recruited was not clear) to award degrees on the strength of such evidence as they could assemble, and to classify such students as they could. A majority of Senate refused to accept the argument that such degrees would have little academic worth, and the Senate cast 82 votes to 35 in favour of the proposal. Before the ordinance reached Court in May 1989, the AUT changed its tactics: papers would now be set and the examinations take place after all, but AUT members would withhold the marks until the dispute was settled. Fortunately a national postal ballot, the results of which were announced only at the beginning of June when the examination season was far advanced, declared in favour of accepting the deal offered - 11,549 votes for the settlement, 9,543 against. Only for 1990-91 did the AUT and the CVCP succeed in agreeing a pay increase of 9 per cent which exceeded the predicted rate of inflation.

In the middle to late 1980 s pay settlements sought, not only to provide for general increases in salaries, but to clear the blockage in promotions and to provide other incentives to good performance. A portion of the money awarded was to be set aside for the purpose. They also strove to provide modest rewards, in the shape of additional increments or 'discretionary salary points', for academics who had done well or shouldered extra responsibilities. Such discretionary points proved attractive once it became clear that those who received them would not lose tenure, for discretionary points called for no new contract and were not supposed to be everlasting rewards (in theory they could be withdrawn after three years, but in practice seldom were). The process of agonising over the award of discretionary points added to the burdens of heads of departments, deans and former deans. New salary scales came into operation. Lecturers were placed on Grade A (the lower grade) or Grade B (the higher), and did 
not automatically advance from the first to the second grade, with its range of higher salary points. Unsatisfactory performers could be kept on Grade A until they improved, but proficient ones could move up to Grade B even before their probation had ended.

Few promotions to senior lectureships had been made in the early and mid-1980s, when the idea of rewarding everyone who reached a good but widely attainable standard had virtually disappeared, and fierce competition had supervened, allowing only candidates of exceptional achievements to succeed. In 1989, however, Senate approved twenty promotions, as in the years before the crisis of 1981-84. Two separate operations, whose results were announced in February and May 1990, cleared some of the backlog. Sixty-four promotions to senior lecturer, senior staff tutor or senior research fellow were then made, and twenty of these were reserved for good all-rounders and departmental stalwarts - persons at the top of the Grade B scale who were unlikely to gain promotion by the usual criteria, but had 'made a strong, positive and continuing contribution to the Department across a range of activity'.

For years lecturers had complained that promotions depended too heavily on research achievements and failed to reward good teaching. Judgements on teaching were haphazard, depending too much on anecdotal or impressionistic evidence. It was all too easy for a professor, urging the case of a good publisher, to exaggerate the candidate's excellence as a teacher and never be challenged. In 1990 a working party under Professor Cox of English attempted to tackle the problem. 'Teaching profiles', accounts of everyone's prowess as a teacher, were to consist of quantitative and qualitative evidence. To establish how many hours people had taught, and how many students, and how many courses, was a laborious but relatively straightforward task. Given the sensitivity of some academics, the job of measuring the quality of teaching was far more difficult; many tutors regarded the classroom as a sanctum that no observer should ever be allowed to invade.

Cox and his party did not discuss at length the problems of using student questionnaires, though many professors could have testified on the subject. Students, said some critics, would applaud charlatans, and enthuse about spectacular performers in colourful but conventional subjects; they would comment maliciously on rigorous teachers who tackled demanding issues, told no jokes, repeated no entertaining anecdotes, and refused to tell them what to think or to provide, in lectures and tutorials, substitutes for reading books. However, few lecturers who did well out of questionnaires were inclined 
to question their value. In defence of questionnaires it could be said that, though students were not experts on the content of their courses, they were experts on their own reactions to them, and could properly be consulted. They were likely to act responsibly, especially if they were advised that their judgements could affect lecturers' careers. If they could not hear properly, or found that too much knowledge was assumed, or were anaesthetised by a lecturer's monotonous tones and unenthusiastic demeanour, that critical information, if obviously given in good faith, was highly relevant and could profitably be used.

Cox and his colleagues, however, pronounced in favour of scrutiny by academic peers. Let a group of colleagues attend a lecture or seminar by each member of staff about once every three years or perhaps every five, and adopt some sort of scoring system in order to assess the performance. It seemed that they had nothing very rigorous in mind, and the mere fact of being observed was liable to change behaviour; but perhaps there were a few academics who could not give a decent lecture, even occasionally, and even when warned in advance.

Endless arguments arose as to whether the new and increasingly formal system of management adopted in the wake of Jarratt would actually make the University more effective. It provided machinery for procuring a general level of efficiency, keeping everyone up to the mark by constant scrutiny and seeking to motivate academics by material rewards and gains in status. In abeyance was the liberal notion that academics should be their own managers, doing their own work with some encouragement from colleagues and friends. Growing insecurity, affecting the young people without tenure rather than the middle-aged who continued to enjoy it, might act as a healthy stimulus. For many folk, it might be argued, jobs for life had not provided a chance to carry out great enterprises, to delay for twenty years before publishing some work of huge significance in its field. On the contrary, they had tempted academics to take life easily and surrender to an undemanding routine. One might well wonder, though, whether the practice of accentuating hierarchy in the new form of line management would make the University more original, creative or inspiring. Much time would now be diverted to the systematic compilation of records, documents, programmes and codes of practice, and to sitting in judgement on colleagues. So-called 'efficiency gains' were often no more than euphemisms or flimsy pretexts for cuts, exercises in doing things, not better, but with less expenditure of time and 
money. Preoccupation with measuring performance, talk of accountability, in order to demonstrate that universities gave value for the money allotted to them, became increasingly insistent and oppressive. From the mid-1980s a growing concern, perhaps the gravest of all, was with the quality of the University's research as judged by outside bodies, and that will be the subject of the next chapter. 